Jurnal Health Sains: p-ISSN : 2723-4339 e-ISSN : 2548-1398

Vol. 2, No. 2, Februari 2021

\title{
GAMBARAN TINGKAT PENGETAHUAN IBU TENTANG TUMBUH KEMBANG BALITA DI DESA LANGKE KECAMATAN GENTUMA RAYA PROVINSI GORONTALO
}

\author{
Andro Ruben Runtu, Amelia Rattoe dan Rosita Siska Kalalo
}

Akademi Keperawatan Bethesda Tomohon, Kota Tomohon, Sulawesi Utara

Email: androruntu21@gmail.com, ameliarattoe67@gmail.com dan rositaskalalo94@gmail.com

\begin{tabular}{l}
\hline ARTIKEL INFO \\
\hline Tanggal diterima: 5 Februari \\
2021 \\
Tanggal revisi: 15 Februari \\
2021 \\
Tanggal yang diterima: 25 \\
Februari 2021 \\
Keywords: \\
Knowledge, Growth, Toddlers
\end{tabular}

\begin{abstract}
The term growth actually includes two events of different nature, but the two are interconnected so it is difficult to separate. Stimulation in growing up in toddlers is important to be considered especially by mothers as the closest person to toddlers. The general purpose of this research is to know the level of maternal knowledge about the growth of toddlers in langke village, Gentuma Raya sub-district at a good level, enough, and less. This type of research is descriptive, sampling techniques with total sampling with a sample number of 35 respondents, location and time of research in the village langke District Gentuma Raya in June-July 2020, research instruments using questionnaires. The results of the study of 35 respondents obtained the results of respondents who have good knowledge as many as 8 respondents (22\%), enough 23 as many as respondents (65.7\%), less as many as 4 respondents (11.4\%). Based on the work of almost all respondents are Housewives (IRT) 29 respondents (82.9\%), the majority of high school education 18 respondents (51.4\%), with ages 17-23 and 24-29 years. Based on the results of research on the mother's knowledge about the growth of toddlers in the village langke Gentuma Raya district is still in the range of enough $(65.7 \%)$, it is recommended to mothers to be able to follow the program in existing health facilities because the knowledge of the mother will be the determinant of attitudes and behaviors in providing nutrition, affection, and frequency of stimulation given to toddlers.
\end{abstract}

\begin{abstract}
ABSTRAK
Istilah tumbuh kembang sebenarnya mencakup dua peristiwa yang sifatnya berbeda, namun keduanya saling berkaitan sehingga sulit untuk dipisahkan. Stimulasi dalam tumbuh kembang pada balita merupakan hal yang penting untuk diperhatikan terutama oleh ibu sebagai orang terdekat dengan balita. Tujuan umum penelitian ini adalah mengetahui tingkat pengetahuan ibu tentang tumbuh kembang balita di desa Langke Kecamatan Gentuma Raya

pada tingkat baik, cukup, dan kurang. Jenis penelitian ini adalah deskriptif, teknik pengambilan sampel dengan total sampling dengan jumlah sampel 35 responden, lokasi dan
\end{abstract}

Kata Kunci:

Pengetahuan; Tumbuh

Kembang; Balita 


\begin{tabular}{l}
\hline waktu penelitian di desa Langke Kecamatan Gentuma Raya \\
pada bulan Juni-Juli 2020, instrument penelitian \\
menggunakan kuesioner. Hasil penelitian dari 35 responden \\
diperoleh hasil responden yang memiliki pengetahuan baik \\
sebanyak 8 responden $(22 \%)$, cukup sebanyak 23 responden \\
$(65,7 \%)$, kurang sebanyak 4 responden (11,4\%). \\
Berdasarkan pekerjaan hampir semua responden adalah Ibu \\
Rumah Tangga (IRT) 29 responden (82,9\%), mayoritas \\
pendidikan terakhir SMA 18 responden (51,4\%), dengan \\
usia 17-23 dan 24-29 tahun. Berdasarkan hasil penelitian \\
pengetahuan ibu tentang tumbuh kembang balita di Desa \\
Langke Kecamatan Gentuma Raya masih di rentang cukup \\
(65,7\%), disarankan kepada ibu agar dapat mengikuti \\
program di fasilitas kesehatan yang ada karena pengetahuan \\
ibu akan menjadi penentu terhadap sikap dan perilaku dalam \\
memberikan nutrisi, kasih sayang, dan frekuensi stimulasi \\
yang diberikan kepada balita.
\end{tabular}

Coresponden Author:

Email: androruntu21@gmail.com Artikel dengan akses terbuka dibawah lisensi

\section{Pendahuluan}

Perkembangan adalah bertambahnya kemampuan (skill) dalam struktur dan fungsi tubuh yang komplek dalam pola yang teratur sebagai hasil dari proses pematangan pada balita, terjadi proses pertumbuhan dan perkembangan yang sangat cepat (Khairi, 2018). Pertumbuhan tubuh dan keterampilan motorik meningkat dengan sangat jelas dan signifikan. Selain itu, pada masa balita juga merupakan tahapan penting dalam perkembangan struktur dan fungsi otak dimana koneksi antar jaringan saraf terbentuk sempurna pada masa ini (Muflikhah, 2019).

Status gizi merupakan salah satu faktor yang dapat mempengaruhi pertumbuhan dan perkembangan anak (Gunawan et al., 2016). Beberapa faktor yang dapat mempengaruhi pertumbuhan dan perkembangan anak di negara berkembang seperti kemiskinan, malnutrisi, sanitasi kesehatan yang buruk serta kurangnya stimulasi dari lingkungan. Anak dengan status gizi kurang akan mengalami pertumbuhan dan perkembangan yang terhambat dan tidak optimal sesuai dengan tahapan usianya (Ningtyas et al., 2017).

Menurut (Organization, 2013), jumlah penderita gizi kurang di dunia mencapai 104 juta anak dan keadaan gizi kurang masih menjadi penyebab sepertiga dari seluruh penyebab kematian anak diseluruh dunia. Asia Selatan merupakan wilayah dengan prevalensi gizi kurang terbesar di dunia, yaitu sebesar 46\% kemudian wilayah sub-Sahar Afrika $28 \%$, Amerika Latin $7 \%$ dan yang paling rendah terdapat di Eropa Tengah, Timur. UNI CEF melaporkan sebanyak 167 juta anak prasekolah di dunia yang menderita gizi kurang sebagian besar berada di Asia Selatan (Gupta et al., 2016).

Pada tahun 2018 di Indonesia terdapat $17,7 \%$ balita kekurangan gizi yang terdiri dari $3,9 \%$ balita dengan gizi buruk dan 13,8\% balita dengan gizi kurang. Jika dibandingkan dengan tahun 2017 balita kekurangan gizi $17,8 \%$ yang terdiri dari $3,8 \%$ balita dengan gizi buruk dan $14 \%$ balita dengan gizi kurang. Jumlah balita di Provinsi Gorontalo tahun Jurnal Health Sains Vol. 2, No. 2, Februari 2021 
2019 sebanyak 113.200. Persentase balita dengan gizi kurang $(\mathrm{BB} / \mathrm{U})$ provinsi Gorontalo tahun 2019 sebesar 17,5\%. Sedangkan balita dengan gizi buruk tahun 2019 sebesar 14,44\% (Kemenkes RI, 2016).

Jumlah balita di Desa Langke selama tahun 2019 sebanyak 45 balita. Terdiri dari usia 1-3 tahun 20 balita dan usia 4-5 tahun 25 balita pada bulan Januari 2020 sebanyak 35 balita. Semua balita memiliki kartu menuju sehat (KMS). Hasil wawancara pada $10 \mathrm{ibu}$ yang memiliki balita, tentang tumbuh kembang balita dengan 2 pertanyaan: pengertian dan faktor-faktor yang memepengaruhi tumbuh kembang anak, didapat hasil 2 orang ibu mampu menjawab petanyaan dengan benar, ibu mengetahui tentang pengertian tumbuh kembang dan dapat menyebutkan faktor-faktor yang mempengaruhi tumbuh kembang balita, sedangkan untuk 8 orang ibu tidak dapat menjawab pertanyaan dengan benar.

Masa anak di bawah lima tahun merupakan periode penting dalam tahap kehidupan manusia. Stimulasi dalam tumbuh kembang pada balita merupakan hal yang penting untuk diperhatikan terutama oleh ibu sebagai orang terdekat dengan balita (Ahmad Susanto, 2011). Pengetahuan ibu akan menjadi penentu terhadap sikap dan perilaku dalam memberikan nutrisi, kasih sayang, dan frekuensi stimulasi yang diberikan kepada anaknya (Hasanah, 2019) . Maka dari itu, jika pengetahuan baik maka ibu akan mengetahui bagaimana tumbuh kembang yang optimal. Tingkat pengetahuan ibu tentang tumbuh kembang balita di Indonesia masih bervariasi, selain itu berdasarkan studi pendahuluan yang telah dilakukan di desa Langke Kecamatan Gentuma Raya dari 10 ibu hanya 2 yang mampu menjawab pertanyaan tentang tumbuh kembang balita dengan baik. Untuk provinsi Gorontalo khususnya di desa Langke belum ada yang melakukan penelitian tentang pengetahuan ibu tentang tumbuh kembang balita, maka dari itu penulis tertarik untuk melakukan penelitian tentang tumbuh kembang balita. Dengan demikian masalah penelitian ini adalah gambaran pengetahuan ibu tentang tumbuh kembang balita. Pertanyaan yang terkait dengan rumusan pada penelitian ini adalah bagaimana gambaran pengetahuan ibu tentang tumbuh kembang balita. Tujuan umum penelitian ini bertujuan untuk mengetahui gambaran tingkat pengetahuan ibu tentang tumbuh kembang balita di desa langke kecamatan gentuma raya provinsi gorontalo. Tujuan khusus Untuk mengetahui karakteristik ibu balita. karakteristik umur, pendidikan, pekerjaan, serta untuk mengetahui tingkat pengetahan ibu tentang tumbuh kembang balita.

\section{Metode Penelitian}

Desain penelitian ini adalah deskriptif. Deskriptif yaitu sebuah desain penelitan yang menggambarkan fenomena yang ditelitinya dan menggambarkan besarnya masalah yang diteliti (Swarjana et al., 2015). Penelitian deskriptif bertujuan untuk mendapatkan gambaran yang akurat dari sejumlah karakteristik masalah yang diteliti (Suyanto \& Salim, 2011). Populasi dalam penelitian ini semua ibu yang mempunyai balita yang ada di Desa Langke Kecamatan Gentuma Raya. Teknik yang digunakan dalam penelitian ini adalah total sampling adalah teknik pengambilan sampel dimana jumlah sampel sama dengan jumlah populasi atau dalam kata lain semua populasi dijadikan sampel seluruhnya (Suyanto \& Salim, 2011). Instrumen penelitian yang digunakan berupa kuesioner atau angket dengan beberapa pertanyaan.

Penelitian ini dilaksanakan di Desa Langke Kecamatan Gentuma Raya Kabupaten Gorontalo Utara Provinsi Gorontalo. Tenaga kesehatan yang ada di Desa Langke terdiri dari 1 orang dokter, 1 orang perawat, dan 6 kader yang melayani melalui pelayanan kegiatan 
posyandu. Jenis pelayanan yang diberikan antara lain kesehatan ibu dan anak yang meliputi pemeriksaan imunisasi, ibu hamil, serta pemenuhan kebutuhan gizi. Desa langke terdiri dari dua dusun yaitu dusun Dano dan Aldus. Letak Desa Langke sebelah timur berbatasan dengan Desa Durian, sebelah barat berbatasan dengan Desa Dumolodo, sebelah utara berbatasan dengan Desa Gentuma, sebelah selatan berbatasan dengan kecamatan Tapa.

\section{Hasil Penelitian}

Penelitian ini dilakukan pada bulan Juni 2020 sampai bulan Juli 2020 di Desa Langke Kecamatan Gentuma Raya. Responden dalam penelitian ini adalah ibu yang mempunyai balita yang tercatat di Desa Langke berjumlah 35 responden.

1. Karakteristik umum responden

a. Karakteristik responden berdasarkan umur.

Tabel 5.1

Karakteristik Responden Berdasarkan

\begin{tabular}{lcccc}
\multicolumn{5}{c}{ Umur } \\
\hline Variabel & Mean & $\begin{array}{c}\text { Min- } \\
\text { maks }\end{array}$ & $95 \%$ CI & SD \\
& & & \\
\hline Umur & 24,83 & $17-35$ & $23,38-$ & 4,225 \\
& & & 26,28 & \\
\hline
\end{tabular}

Berdasarkan tabel 5.1, dapat dilihat rerata umur responden adalah 24,83 dengan standar deviasi 4,225.

b. Karakteristik responden berdasarkan Pendidikan.

Tabel 5.2

Karakteristik Responden Berdasarkan Pendidikan

\begin{tabular}{ccc}
\hline Pendidikan & Frekuensi & Persen \\
\hline SD & 4 & $11,4 \%$ \\
\hline SMP & 10 & $28,6 \%$ \\
\hline SMA & 18 & $51,4 \%$ \\
\hline $\begin{array}{c}\text { Perguruan } \\
\text { Tinggi }\end{array}$ & 3 & $8,6 \%$ \\
\hline Total & 35 & $100 \%$ \\
\hline
\end{tabular}

Berdasarkan tabel 5.2 dapat dilihat bahwa sebagian besar responden berpendidikan akhir SMA, yaitu sebanyak 18 responden $(51,4 \%)$.

c. Karakteristik responden berdasarkan pekerjaan.

Tabel 5.3

Karakteristik Responden Berdasarkan Pekerjaan

\begin{tabular}{|c|c|c|}
\hline Pekerjaan & Frekuensi & Persen \\
\hline PNS & 2 & $5,7 \%$ \\
\hline Swasta & 4 & $11,4 \%$ \\
\hline IRT & 29 & $82,9 \%$ \\
\hline Total & 35 & $100 \%$ \\
\hline
\end{tabular}

dilihat bahwa sebagian besar responden adalah sebagai Ibu Rumah Tangga (IRT) sebanyak 29 responden $(82,9 \%)$.

2. Pengetahuan Ibu Tentang Tumbuh Kembang Balita Di Desa Langke Kecamatan Gentuma Raya.

Tabel 5.4

\section{Pengetahuan Ibu Tentang Tumbuh} Kembang Balita.

\begin{tabular}{ccc}
\hline Pengetahuan & Frekuensi & Persen \\
\hline Baik & 8 & $22,9 \%$ \\
\hline Cukup & 23 & $65,7 \%$ \\
\hline Kurang & 4 & $11,4 \%$ \\
\hline Total & 35 & $100 \%$ \\
\hline
\end{tabular}

Berdasarkan tabel 5.4 dapat dilihat sebagian responden memiliki pengetahuan cukup sebanyak 23 responden $(65,7 \%)$.

\section{Pembahasan}

1. Karakteristik Responden

Berdasarkan hasil penelitian yang dilakukan di Desa Langke Kecamatan Gentuma Raya Provinsi Gorontalo dilihat dari karakteristik umur responden rerata umur responden 24,83 dengan standar deviasi 4,225. Hal ini sejalan dengan penelitian yang dilakukan (Vernieres et al., 2017), menunjukkan bahwa rentang umur responden 19-36 tahun. Umur 
mempengaruhi daya tangkap dan pola pikir seseorang. Semakin bertambah usia akan semakin bertambah pula daya tangkap dan pola pikir sehingga pengetahuan yang diperolehnya semakin membaik (Usman et al., 2014). Pada usia muda, individu akan lebih berperan aktif dalam masyarakat dan kehidupan sosial, serta lebih banyak melakukan persiapan untuk menyesuaikan diri menuju usia tua. Pada usia ini kemampuan intelektual, pemecahan masalah, dan kemampuan verbal hampir tidak ada penurunan. Hasil penelitian ini menunjukkan bahwa umur responden berada pada usia muda dimana lebih berperan aktif dalam masyarakat dan kehidupan sosial serta lebih banyak melakukan persiapan untuk menyesuaikan diri menuju usia tua berdasarkan pengalaman sebelumnya. Umur tidak berpengaruh dalam pengetahuan responden tentang tumbuh kembang balita karena sebagian besar responden berumur 17-23 tahun, 24-29 tahun berpengetahuan cukup.

Berdasarkan karakteristik
pendidikan dari 35 responden, yang diteliti, responden yang terbanyak memiliki Pendidikan SMA yaitu sebanyak 18 responden $(51,4 \%)$. Hal ini sejalan dengan penelitian yang dilakukan oleh Vera Ningtyas, (2017) menunjukkan bahwa 31 responden $(58,5 \%)$ merupakan responden yang berpendidikan terakhir SMA. Pendidikan adalah suatu usaha untuk mengembangkan kepribadian dan kemampuan di dalam dan diluar sekolah (baik formal maupun nonformal), berlangsung seumur hidup. Pendidikan adalah sebuah proses pengubahan sikap dan tata laku seseorang atau kelompok dan juga usaha mendewasakan manusia melalui upaya pengajaran dan pelatihan. Pendidikan mempengaruhi proses belajar, semakin tinggi pendidikan seseorang, makin mudah orang tersebut menerima informasi (Usman et al., 2014).

Hasil penelitan menunjukkan bahwa yang memiliki pengetahuan cukup terbanyak adalah ibu yang memiliki pendidikan terakhir SMA. Namun hal ini tidak menunjukkan bahwa seseorang yang memiliki pendidikan menengah memiliki pengetahuan yang kurang tentang tumbuh kembang balita. Hal ini dkarena pengetahuan tidak hanya dapat diperoleh dari pendidikan formal saja, tetapi ada beberapa faktor yang mempengaruhi pengetahuan ibu tentang tumbuh kembang balita, misalnya pengalaman sendiri, pengalaman orang lain, dukungan dari orang lain, maupun respon fisiologis dari ibu tersebut.

Berdasarkan karakteristik pekerjaan yang diteliti 29 responden (82,9\%) tidak bekerja atau sebagai ibu rumah tangga. Hal ini sejalan dengan penelitian yang dilakukan (Fatnamartiana, 2018) dari 95 responden yang diteliti 82 responden $(85,4 \%)$ tidak bekerja atau sebagai ibu rumah tangga. Pengalaman belajar dalam bekerja yang dikembangkan akan memberikan pengetahuan dan keterampilan professional, serta dapat mengembangkan kemampuan mengambil keputusan yang merupakan manifestasi dari keterpaduan menalar secara ilmiah dan etik yang bertolak dari masalah nyata dalam bidang kerjanya (Usman et al., 2014). Hasil penelitian menunjukkan bahwa ibu yang memiliki pengetahuan cukup tentang tumbuh kembang balita adalah ibu yang tidak memiliki pekerjaan atau sebagai ibu rumah tangga. Hal ini dikarenakan ibu yang tidak bekerja memiliki lebih banyak waktu dengan balitanya sehingga setiap perkembangan dapat dipantau secara langsung.

2. Gambaran tingkat pengetahuan ibu tentang tumbuh kembang balita di Desa Langke 
Kecamatan Gentuma Raya Provinsi Gorontalo.

Penelitian ini menggambarkan tingkat pengetahuan ibu tentang tumbuh kembang balita pada seluruh responden berdasarkan hasil skor pengetahuan ibu tentang tumbuh kembang balita yang didapatkan pada jawaban responden. Penilaian bersifat positif dari rentang nilai 10 hingga 20, nilai 20 merupakan nilai tertinggi. Penelitian ini menggunakan tiga kategori yaitu kategori kurang 0 hingga 10 . Kategori cukup 11 hingga 14, kategori baik 15 hingga 20. Berdasarkan hasil penelitian yang telah dilakukan di Desa Langke Kecamatan Gentuma Raya Provinsi Gorontalo menunjukkan bahwa dari 35 responden yang diteliti pengetahuan baik sebanyak 8 responden (22,9\%), pengetahuan cukup sebanyak 23 responden $(65,7 \%)$, dan pengetahuan kurang sebanyak 4 responden $(11,4 \%)$. Hal ini sejalan dengan penelitian sebelumnya yang dilakukan oleh Muzayyantul (2014) mengenai gambaran pengetahuan ibu balita tentang tumbuh kembang balita usia 0-5 tahun di Posyandu Karangbedo, Banguntapan, Bantul yang menunjukkan dari 55 responden didapatkan ibu yang memiliki pengetahuan cukup tentang tumbuh kembang balita yaitu sebanyak 41 responden $(75 \%)$.

Hal tersebut menunjukkan bahwa pengetahuan tentang tumbuh kembang balita pada semua responden yang diteliti sudah baik. Hasil penelitian ini juga menunjukkan bahwa karakteristik responden seperti umur, jenis kelamin, pendidikan, serta pekerjaan tidak mempengaruhi tingkat pengetahuan ibu tentang tumbuh kembang balita. Pengetahuan adalah suatu hasil dari rasa keingintahuan melalui proses sensoris, terutama pada mata dan telinga terhadap objek tertentu. Pengetahuan merupakan domain yang penting dalam terbentuknya perilaku terbuka atau open behavior. Pengetahuan atau knowledge adalah hasil penginderaan manusia atau hasil tahu seseorang terhadap suatu objek melalui pancaindra yang dimilikinya. Pancaindra manusia guna penginderaan terhadap objek yakni penglihatan, pendengaran, penciuman, rasa dan perabaan. Pada waktu penginderaan untuk menghasilkan pengetahuan tersebut dipengaruhi oleh intensitas perhatian dan persepsi terhadap objek. Pengetahuan seseorang sebagian besar diperoleh melalui indra pendengaran dan indra penglihatan (Usman et al., 2014). Pengetahuan tentang tumbuh kembang balita sangat penting bagi ibu, hal ini di karenakan tingkat pengetahuan ibu dapat mempengaruhi keberhasilaan dalam tumbuh kembang balita karena pada umumnya ibu yang mempunyai hubungan paling dekat dengan balita. Keberhasilan tumbuh kembang pada usia balita sangat berpengaruh pada usia selanjutnya.

a. Implikasi terhadap keperawatan

Pengetahuan tentang tumbuh kembang balita sangat penting bagi ibu, hal ini dikarenakan tingkat pengetahuan ibu dapat mempengaruhi keberhasilaan dalam tumbuh kembang balita pada usia selanjutnya. Pada penelitian ini terlihat bahwa seluruh responden sudah memiliki pengetahuan cukup baik dari persentase yang dihasilkan.

Hasil penelitian ini menunjukkan bahwa kurangnya tingkat pengetahuan ibu tentang tumbuh kembang balita bukan menjadi penyebab utama kurangnya gizi pada balita ada faktor lain yang mempengaruhi seperti adat istiadat ekonomi yang rendah, budaya setempat atau kebiasaan-kebiasaan, acuh tak acuh. Hasil penelitian ini 
dapat menjadi dasar bagi tenaga kesehatan melakukan upaya untuk meningkatkan tingkat pengetahuan ibu tentang balita. Upaya tersebut dapat dilakukan dengan cara memberikan edukasi kesehatan saat posyandu di institusi pelayanan kesehatan seperti rumah sakit dan puskesmas.

b. Keterbatasan penelitian Peneliti menyadari masih banyak keterbatasan dalam penelitian yang telah dilakukan. Keterbatasan dalam penelitian ini dikarenakan adanya pandemic COVID-19 menyebabkan peneliti harus melakukan penelitian dengan cara door to door (rumah ke rumah) karena untuk sementara pelayanan posyandu tidak dijalankan. Keterbatasan lainnya yang ditemui peneliti yaitu jumlah responden yang sedikit tidak bisa menemui responden secara langsung dalam satu waktu, sehingga membutuhkan waktu yang lama karena setia responden memiliki waktu luang yang berbeda serta waktu penelitian yang terbatas.

\section{Kesimpulan}

Dari hasil penelitian yang telah dilakukan disumpulkan bahwa sebagian besar ibu yang memiliki balita sebanyak 23 responden $(65,7 \%)$ memiliki pengetahuan cukup tentang tumbuh kembang balita, sehingga diharapkan bagi pelayanan kesehatan dapat meningkatkan kualitas pelayanan kesehatan khususnya pada ibu dalam pemberian edukasi pada ibu tentang tumbuh kembang balita. Bagi peneliti selanjutnya dapat meneliti fenomena yang ada dan melakukan penelitian dengan metode yang berbeda, dalam mengembangkan variable penelitian dan kuesioner yang lain.

\section{BIBILIOGRAFI}

Ahmad Susanto, M. P. (2011). Perkembangan Anak Usia Dini: Pengantar Dalam Berbagai Aspeknya. Kencana.

Fatnamartiana, S. (2018). Gambaran Pengetahuan Ibu Tentang Stimulasi Tumbuh Kembang Balita Di Wilayah Kerja Puskesmas Guntur Kabupaten Garut.

Gunawan, G., Fadlyana, E., \& Rusmil, K. (2016). Hubungan Status Gizi Dan Perkembangan Anak Usia 1-2 Tahun. Sari Pediatri, 13(2), 142-146.

Gupta, A., Vedaldi, A., \& Zisserman, A. (2016). Synthetic Data For Text Localisation In Natural Images. Proceedings Of The IEEE Conference On Computer Vision And Pattern Recognition, 2315-2324.

Hasanah, M. N. (2019). Hubungan Pengetahuan Ibu Tentang Stimulasi Bahasa Dengan Perkembangan Bahasa Pada Anak Usia 1-3 Tahun Di Desa Lengkong Kecamatan Mumbulsari Jember.

Kemenkes RI. (2016). Profil Kesehatan Indonesia Tahun 2015. In Jakarta: Kementerian Kesehatan Republik Indonesia.

Khairi, H. (2018). Karakteristik Perkembangan Anak Usia Dini Dari 0-6 Tahun. Jurnal Warna, 2(2), 15-28.

Muflikhah, K. (2019). Optimalisasi Tumbuh Kembang Balita Di Desa Karangklesem Melalui Peningkatan Kemampuan Ibu Dalam Melakukan Stimulasi Tumbuh 
Kembang Sesuai Umur Secara Mandiri. Prosiding, 8(1).

Ningtyas, J. D. A., Si, M., \& Pusmanu, P. (2017). Penyusunan Laporan Keuangan UMKM Berdasarkan Standar Akuntansi Keuangan Entitas Mikro, Kecil Dan Menengah (SAK-EMKM)(Study Kasus Di UMKM Bintang Malam Pekalongan). Riset \& Jurnal Akuntansi, 2(1), 11-17.

Organization, W. H. (2013). Global Tuberculosis Report 2013. World Health Organization.

Suyanto, \& Salim, R. (2011). Foreign Direct Investment Spillovers And Technical Efficiency In The Indonesian Pharmaceutical Sector: Firm Level Evidence. Applied Economics, 45(3), 383-395.

Swarjana, I. K., SKM, M. P. H., \& Bali, S. (2015). Metodologi Penelitian Kesehatan [Edisi Revisi]: Tuntunan Praktis Pembuatan Proposal Penelitian Untuk Mahasiswa Keparawatan, Kebidanan, Dan Profesi Bidang Kesehatan Lainnya. Penerbit Andi.

Usman, S., Notoadmodjo, S., Rochadi, K., \& Zuska, F. (2014). Changing Smoking Behavior Of Staff At Dr. Zainoel Abidin Provincial General Hospital, Banda Aceh. Advances In Public Health, 2014(12), 22.

Vernieres, J., Steinhauer, S., Zhao, J., Chapelle, A., Menini, P., Dufour, N., Diaz, R. E., Nordlund, K., Djurabekova, F., \& Grammatikopoulos, P. (2017). Gas
Phase Synthesis Of Multifunctional Fe Based Nanocubes. Advanced Functional Materials, 27(11), 1605328. 